\title{
Business Roadmap Model: A Review of Research
}

\author{
Finnah Fourqoniah,", Riyan Danu Setiawan', and Muhammad Fikry Aransyah ${ }^{3}$ \\ ${ }^{1,2,3}$ Mulawarman University, Samarinda, Indonesia \\ "Email: fienfour@gmail.com
}

\begin{abstract}
In doing business, business actors must understand the importance of a business model in entrepreneurship; a business strategy is needed. There are several business models, but the one most often used by business actors is the Business Model Canvas or what we usually know (BMC). According to several studies, the Business Model Canvas is a business model that can still be developed into a more detailed business model and better mapping. Then from the Business Model Canvas, a new business model was developed, namely the Business Road Map, to win the market competition. Business Road Map is a pattern or Business Mapping Method to build a business model/business plan capable of creating growth over time.
\end{abstract}

Keywords: Business Model; Business Model Canvas; Business Road Map; Business Development

\section{Introduction}

Business Roadmap is a business model for developing the Business Model Canvas, which has just been discovered and used in several MSMEs. Even though it is relatively new, the Business Road Map is considered suitable for MSMEs to use in business to win the market competition. Creating several versions of their business model enables them to evaluate alternatives and maintain the business model's evolutionary history (Pigneur \& Fritscher, 2000). We find patterns of business models that provide a visual representation of the business's dynamics by depicting the flow of information, value, and money (Rosello, 2019).

From this business model phenomenon, the researchers considered that the Business Roadmap's research topic was quite interesting to study because it had a considerable influence on existence in the world business. Especially in businesses where the barrier to entry is quite tight in some small businesses, their age does not last long. To result in the business going bankrupt or closing. Managers and decision-makers can generate new business models or adapt existing business models more systematically (Diener \& Luttgens, 2016).
In doing business, business actors must understand the importance of a business model. The business model describes how business activities and strategies are carried out. Business models are made to be seen, understood and implemented by all business stakeholders. There are several business models, but the one most often used is the Business Model Canvas or what we usually know as (BMC). Then from the Business Model Canvas, a new business model was developed, namely the Business Road Map (BRM).

Rapid business changes require organizations to do proper planning. Failing to plan means planning to fail. The road map is very helpful in motivating employees to know the organization's goals for the next 5-10 years. A detailed action plan will help achieve the target. This model aims to reduce errors in preparing business plans at the beginning of the year, maintain existing businesses, and facilitate business expansion in a competitive environment. Business Roadmap Models (BRM) is a tool that can help anyone serious about doing business with careful planning and is designed to get a clear cash profit.

From this business model phenomenon, the researcher considers the Business Roadmap research topic quite interesting to

Received: 26-02-2021; Revised: 24-08-2021; Accepted: 24-08-2021; Published: 30-09-2021; Available

online: 30-09-2021 DOI: https://doi.org/10.14710/jab.v10i2.36974 
study because it can describe several strategies that must be carried out to win the competition. Especially in businesses where the entry barrier is quite tight for micro and small businesses, their age often does not last long. Improper strategies result in the business going bankrupt or closing. One of the reasons is the lack of understanding of business strategy and how to run it. One solution is to use a business model canvas so that business mapping is more structured and understood by all stakeholders of the business organization. Managers and decision-makers can generate the best business models or adapt existing business models more systematically (Diener \& Luttgens, 2016). We find business model patterns that provide a visual representation of the dynamics behind a business by depicting the flow of information, value, and money (Rosello, 2019). To create multiple versions of their business model, enabling them to evaluate alternatives and maintain the evolutionary history of the business model (Fritscher, 2000).

Several studies explain the business model as a business strategy used by business actors in various business fields. What distinguishes this research is the application of the business model of each business actor. The cause of the difference lies in the problems encountered by each business actor. To solve the problem, they cannot use the same strategy. However, the same business model can be used by looking back at the problems encountered and then analyzing the problem after formulating a suitable strategy. According to previous research, it can be explained that the Business Model can still be developed again, such as a business model developed into a Business Model Canvas. And then, the Business Model Canvas will be developed into a Business Road Map. According to several studies conducted related to Business Model Canvas research in the property sector (Rudi, 2016), in the social sector (Meranga, 2019), the distribution sector (Saputra \& Widjaja, 2019), the service sector (Sanim et al., 2016), in the distribution sector (Gata \& Alpedro, 2019), (Sultan \& Fatricia, 2019), (Tantriana, 2018), (Alfarisi, 2019), (Hubeis et al., 2014), (Winandi et al., 2019), (Pasaribu \& Harfiani, 2019) (Kosasi, 2015), (Hidayat et al., 2020).
The Road Map Business Development is carried out by adding various elements that need attention which in the BMC model have not been described in detail. Adding elements to the Road Map business is a description of activities that can reinforce the business position in market competition.

Research is the literature from several journals and will be used to identify business models' effect on success or existence in world business. This study will present the influence of business models on success or existence in the world of business. These research results are expected to reference entrepreneurs and SMEs in pioneering and developing a business.

\section{Literature Review}

Micro, Small and Medium Enterprises (MSMEs)

MSMEs are Micro, Small, and Medium Enterprises engaged in all types of businesses such as fashion, culinary, workshops, convenience stores, and clinics. According to Law No. 20 of 2008 concerning MSMEs, the difference between MSMEs only lies in the limitation of assets and turnover. To facilitate the design of the general model, the researchers grouped MSMEs based on their business processes, such as: (1) MSMEs Goods production (production) is a business that produces goods by converting raw materials into finished materials and selling the goods produced; (2) MSME Service Providers (services) is a type of business that provides services and sells goods; (3) MSME Sales of goods (retail) is a type of business that sells goods.

\section{Business Model Canvas}

Business Model Canvas is a visual representation tool that can comprehensively explain a business process. Making a business model canvas is the first thing that usually a beginner entrepreneur needs. With this BMC tool, we can understand a business without making a lengthy business plan document. This Business Model Canvas consists of 9 main pillars that summarize business processes: company value, customer segments, and financial structure. With these nine blocks, we can validate whether a 
business idea is potential or not. The 9 main pillars are: (1) Key Partnership, in the industrial world (business), a company cannot develop and run its business without several partners to work with and in the coffee industry. Companies or SMEs engaged in the coffee industry rely heavily on several partners; (2) Key Activities, key activities are activities that determine the success of a business model; (3) Key Resources, key resources describe the essential assets that determine the successful operation of a business model; (4) Value Propositions are fundamental to implement because this will make a product or service more attractive and unique; (5) Customer Relationship, fostering relationships with customers aims to get new customers, keep old customers, and offer old or new products and services to old customers (Frans, 2014); (6) Channel is an element that states how an organization communicates with its customer segments and delivers its value proposition; (7) Customer Segments, customer segments are certain parties that use the organization's services or products according to their needs; (8) Cost Structure, the cost structure describes all costs that arise after this business model's operation; (9) Revenue Streams describes how the organization money from each customer segment.

With the business model canvas approach, the Sumenep batik industry can grow and develop its business through nine blocks (Narto, 2017). Describe the MACo company business model and develop a strategy using the Triple Layer Business Model Canvas (TLBMC) (Sari, 2019).

The concept of a business model has been defined in various ways. Most business model research has described a business model as a description of how a business is conducted by identifying the elements or components that underlie the business model (Fielt, 2013). The description of the business model provides a broad explanation of the important elements (Osterwalder \& Pigneur, 2010), but there are still limitations in determining how these elements are linked. However, business success is arguably defined by linking the efficient flow of inputs through the transformation process and the outputs offered to customers. Osterwalder \& Pigneur (2010) define a model business as a thought that describes how an organization takes actions to create and offer value to customers. Then Osterwalder \& Pigneur (2010) explains that $\mathrm{BMC}$ is a tool that consists of 9 blocks of business elements as follows: (1) Customer segment: Describes the group or organization targeted by the company; (2) Channels: Describes how the company communicates and reaches its customer segments; (3) Customer relationship: Describes what types of relationships the company builds with the targeted customer segments; (4) Value proposition: Describes how products and services are created with various values offered for specific customer segments. The value proposition can include characteristics such as innovation, performance, design, brand/status, and price; (5) Revenue streams: Describes how the company generates revenue from each segment; (6) Key resources: Describes the most important assets needed to make a business model work; (7) Key activities: Describes what the company must do to make the business model work, such as production, troubleshooting, platform and network activities; (8) Key partnerships: Describes how the network of suppliers and partners makes the business model work; (9) Cost structure: Describes all costs incurred to operate the business model.

\section{Discussion}

\section{Business Model Canvas}

Business Model Canvas is a management strategy tool to translate concepts, consumers, infrastructure, and corporate finance into visual elements. The Business Concept Model Canvas duplicates the idea images to have the same and real understanding of brand consumers, expenses, and how the company works.

According to Rudi (2016), the study results show that the business model at PT. Joyo Bekti Indah is related to one another. Meranga (2019) Business Model Canvas fits, namely, one-sided social mission, two-sided social mission, market-oriented social mission and commercially utilized social mission. Saputra \& Widjaja (2019) explain that ecommerce-based online sales help customers 
get products that suit their needs and help in the long-distance ordering process. Sanim et al. (2016) that increasing the value proposition, customer segment, and customer relationships will affect an organization's income. Gata \& Alpedro (2019) show that creating an e-commerce website at Mr Bro's distribution will increase maximum sales and increase market coverage. Sultan \& Fatricia (2019) show that the nine elements of the Business Canvas Model have a relationship. Tantriana (2018) obtained are an overview of nine elements in the Business Model consisting of customer segments, value propositions, customer relationships, customer segments, channels, revenue streams, cost structure, key activities, key resources, and key partnerships.

Chandra (2016) shows that the company's business model requires several additional factors in each business model element to develop and lead the company towards a better future. Alfarisi (2019) results show that Toyosima should use one of the strategies according to the unbundling business model, namely product innovation. Hubeis et al., (2014) study indicate that the business model that KN Fish Farm has carried out has found weaknesses in the 9 BMC elements. Therefore, improvements are made to all elements. Winandi et al. (2019) show that the nine elements of the Business Model Canvas are internal and external factors. The company's strengths and weaknesses in carrying out its business model and what opportunities and threats from externals affect the business process of PT XYZ.

Pasaribu \& Harfiani (2019) showed that CV. Media has succeeded in running a business by implementing nine elements of BMC; this can be seen from the increasing income of the company every year. Kosasih (2015) from the results of a SWOT analysis for business model development, companies are advised to develop customer segments in young families with young children and further increase product innovation. Hidayat et al., (2020) concluded that there are five main steps in making a scheme for implementing the IPMS: developing a strategy, planning a strategy, aligning the organization, implementing, and monitoring and learning.

Business Road Map Development of a Business Model Canvas

Over time in Indonesia, a new business model tool has been discovered, namely the Business Road Map or BRM, which coach Ridwan Abadi discovered. The Business Road Map itself is a business model strategy resulting from the Business Model Canvas development. Several MSMEs have used the Business Roadmap in several cities in Indonesia because it is considered to have many benefits for MSMEs.

Business Road Map is a Business Mapping Method to build a business model/business plan capable of creating growth over time. There are several Business Road maps or BRM tools: (1) Goals; Goals are the goals or the achievement of targeted turnover within a specified period in detail. Starting from annually, monthly, weekly, today; (2) Reality; Reality is a breakdown of the difference in turnover targets obtained if the business is running to pursue the difference in nominal turnover obtained; (3) Definition; a business will be arranged to achieve the goals. The definition of a business to be prepared is to generate cash by helping people sell a product or service; (4) Target Market; Target Market is a potential buyer who must get information and promotions related to the product. So, the owner needs to take the right steps to reach consumers well the end goal of getting consumers to buy the product. The target market aims to ensure that marketing is on target; (5) Leverage; Leverage or influence is anyone from any group and circle influential in increasing visitors or consumers; (6) Additional Value; Additional Value describes the value or excess of the goods we sell with competitors' goods. What products (goods/services) will you sell? What are the advantages of the product that the owner is selling compared to existing products?; (7) Competitors Analysis; Competitors Analysis is an activity in which sellers or business actors analyze the strengths and weaknesses of a competitor or a competitor as a reference to win the competition; (8) Distribution; Distribution is the distribution process from producers to 
consumers or how customers can get our products online and offline; (9) Funneling; As the process of leading customers to understand our products and why our products are of high value, funneling will enter our business or buy our products; (10) Customer Relationship: Businesses make an effort to retain existing customers by forging strong bonds between customers and business actors; (11) Income Stream; Income Stream is a type of income stream generated whether income or income is generated online, offline or online and offline; (12) Activity; What business activities must be carried out in order for a business to run optimally, be it operations, marketing, finance, or human resources; (13) Skills; What types of abilities must be possessed so that our business can continue to run, for both operational and nonoperational; (14) Resource; Resources are the types of assets and items and materials must have to run a business; (15) Partner; Partners is a co-worker or support tool for businesses running either the raw material tool's supplier or suppliers; (16) Cost Structure; Cost Structure is a breakdown of all types of costs generated in running a business, be it cost of goods sold (COGS), raw materials, and others.
Business RoadMap does not reject or eliminate existing elements of BMC. The Business Road Map (BRM) offers elements such as goals, reality, definition so that business people can better balance idealism, business goals and the reality they face. In these three elements, BRM shows specific business goals in the form of clear achievement figures. This is important for members of the organization to know because its achievement depends on the performance of all components. The current conditions facing the organization are described in the Reality element so that all components are aware of and participate in formulating strategies according to reality. BRM that is understood by all organizational components can involve them in this process.

Furthermore, leverage, distribution and funneling are elements to maximize the implementation of marketing strategy. In BMC, marketing strategy activities are only described in customer relationships and channels. BRM seeks to add some elements that need to be considered by business organizations, especially Micro Small Medium Enterprises (MSMEs). The three additional elements in the Marketing field in BRM are expected to guide business

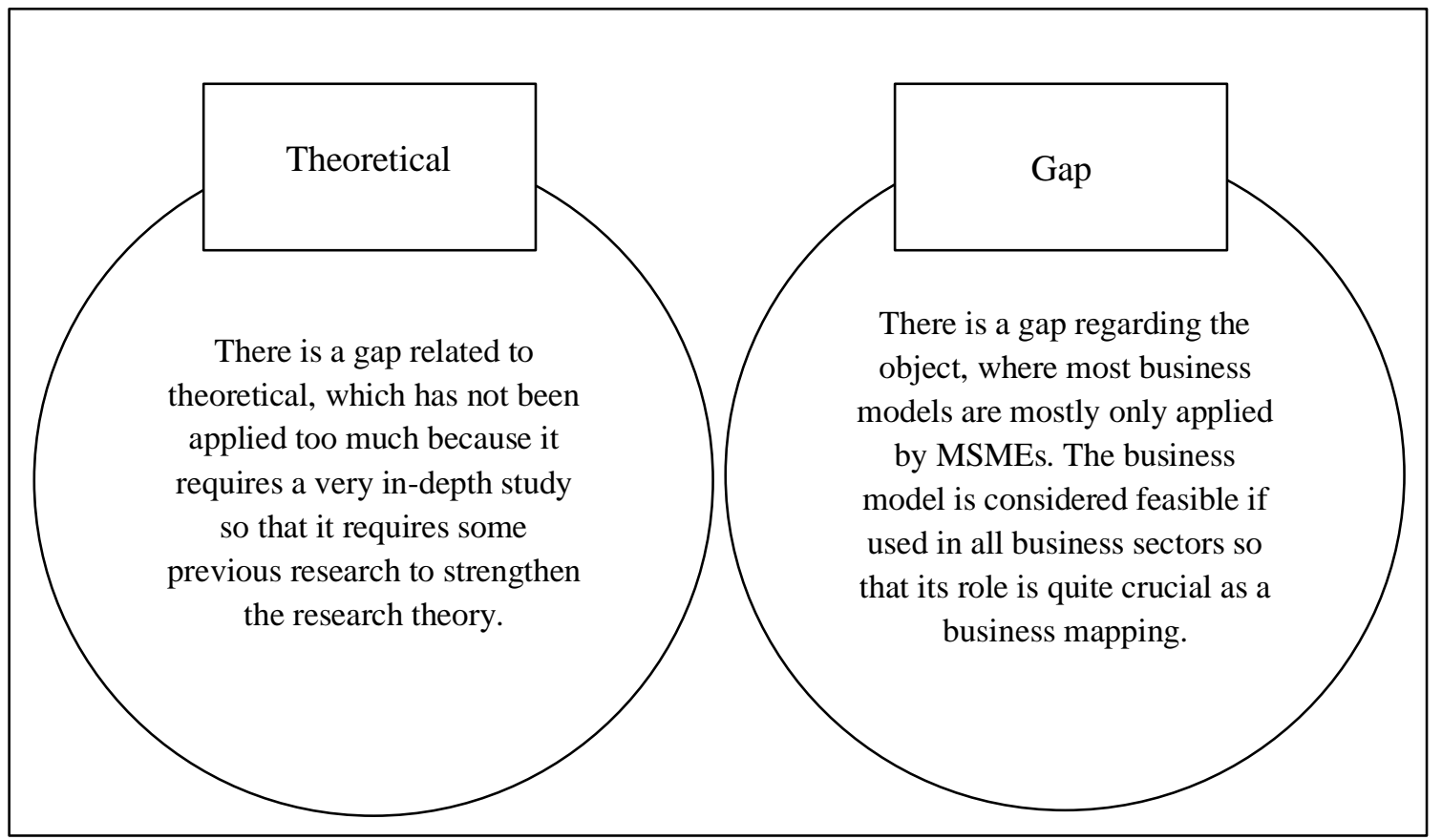

Figure 1. Research Gap

Source: Primary data processed 
organizations in developing the right business strategy.

Key resources elements in $\mathrm{BMC}$ have a function to explain the condition of $\mathrm{HR}$ in business organizations get two additional elements, namely skills and resource elements. BRM believes that a business organization can survive if it has superior human resources and the best resources. These advantages must be known and understood by all components of the organization. BRM explains and communicates this to all stakeholders.

In the end, the element of competition analysis became the main differentiator of BRM from other business model canvases. This element describes what competitors' weaknesses are that can be a way for a business organization to enter the market segment, and what competitors' strengths need to be watched out for. Knowing and understanding the pattern of business competition and developing the best strategy is the way to enter, survive and win the competition in the market.

According to several studies, the Business Model Canvas can still be a business model developed into a more detailed business model and better mapping. According to (Ledy \& Simatupang, 2013), (Pigneur \& Fritscher, 2000), (Rosello, 2019), (Diener \& Luttgens 2016), (Hanelt, Tesch et al. 2016), (Narto, 2017), (Sari, 2019), (Winandi et al., 2019), (Ramadhani \& Putra, 2020). Based on previous studies that have been described above, several research gaps can be identified (Figure 1)

\section{Conclusion}

Business Model Canvas can still be developed. One type of development carried out is Business Road Map so that the business mapping becomes more focused and more detailed. The Business Model Canvas (BMC) is one of the strategic tools used to describe a business model and illustrates the rationale for how organizations create, deliver, and capture value. Meanwhile, a Business Road Map (BRM) is a pattern or Business Mapping Method to build a business model/business plan that can create growth over time. The main contribution is to bring together insights about the business model canvas roadmap and understand its gaps. Business Road Map is one of the developments of a business model that business organizations can use to run and develop a business.

Business organizations can practically implement the Business Roadmap. The Business Roadmap provides a more comprehensive overview of the important elements in the business. The pillars contained in the Business Road Map are used as tools to help analyze the weaknesses of the business being carried out, formulate the best strategy for each element and ensure its implementation in the market.

\section{References}

Adib, S. M., \& Wanda, F. (2019). Implementasi Bisnis Model Kanvas Dalam Perancangan Manajemen Bisnis Aplikasi Jaskost. Jurnal Ilmu Manajemen dan Bisnis, 10(1), 93-100. https://doi.org/1017509/jimb.v10i1.153 38.

Alfarisi, A. (2019). Perencanaan Strategi Business Model Canvas (BMC) Pada Perusahaan Sandal Toyosima Singosari. Jurnal Administrasi Bisnis, 7(2), 1-14. https://jimfeb.ub.ac.id/index.php/jimfeb /article/view/5582/4901.

Azis, E. \& Pratama. (2018). Analisis Model Bisnis Dengan Pendekatan Business Model Canvas (Studi Kasus MxD). Eproceeding of management, 5(3), ISSN: 2355-9357.

https://openlibrarypublications.telkomu niversity.ac.id/index.php/management/a rticle/view/7750.

Chandra, D. (2016). Model Bisnis Pada Perusahaan X Menggunakan Business Model Canvas. AGORA, 4(1), 18-25. http://publication.petra.ac.id/index.php/ manajemen-bisnis/article/view/4219.

Fielt, E. (2013). Conceptualising business models: Definitions, frameworks and classifications. Journal of Business Models, 1(1), 85-105. 
Fritscher \& Pigneur. (2000). Extending the Business Model Canvas: A Dynamic Perspective. Fifth symposium on business modelling and software design, 86-95.

https://www.scitepress.org/papers/2015 158858/pdf/index.html.

Gata \& Alpedro. (2019). Implementasi ECommers Menggunakan Business Model Canvas dan IFML Pada Distor Mr Bro. Jurnal Idealis, 2(6), 369-376. https://jom.fti.budiluhur.ac.id/index.php /IDEALIS/article/view/1882.

Hanelt, A., Jan F.T., Lutz M.K, \& Gerrit. R. (2016). Business Model Patterns Used as a Tool for Creating (new) Innovative Business Models. International Journal of Innovation Management, 21(1). https://doi.org/10.1142/S136391961750 0049.

Hidayat, D., Juhaeri, J., Denies, S., Denok, S., \& Ali, M. (2020). Desain Formulasi Dan Implementasi Bisnis Strategik Dengan Pendekatan Business Model Canvas (BMC) Terintegrasi Kerangka Integrated Performance Management System (IPMS) Pada Koperasi Asperindo. Jurnal Ilmiah Ilmu manajemen, $\quad 7(2), \quad 67-76$. https://dx.doi.org/10.32493/Inovasi.v7i 2.p67-76.8141.

Kusriyanti, T. (2020). Perancangan Strategi Bisnis Dengan Metode Business Model Canvas Pada Leora Design Interior \& Furniture. Jurnal Manajemen Pendidikan dan Ilmu Sosial, 1(2), 527536.

https://doi.org/10.38035/jmpis.v1i2.294

Ledy \& Simatupang. (2013). Constructing a Social Value Navigation Model to Complement A social Organization's Strategy Development Framework. The Indonesian Journal of Business Administration.

https://media.neliti.com/media/publicati ons/69814-EN-pengembangan-modelnavigasi-nilai-sosial.pdf.

Lindriati. T, Ida. B. S, \& Novitha. H. (2019). Penerapan Bisnis Model Kanvas
Dalam Penentuan Rencana Manajemen Usaha Kedelai Edamame Goreng. Jurnal Agroteknologi. 13(1), 42-51. https://doi.org/10.19184/jagt.v13i01.8554.

Luttgens dan Diener. (2016). The Business Model Pattern Database - A Tool for Systematic Business Model Innovation. International Journal of Innovation Management, 21(1). https://doi.org/10.1142/S136391961750 0049.

Kosasi, V. (2015). Analisis dan evaluasi model bisnis pada pantai seafood restaurant dengan pendekatan Model Business Canvas. AGORA, 3(1), 314323.

https://publication.petra.ac.id/index.php /manajemen-bisnis/article/view/2880.

Malasari. (2019). Perancangan Business Model Canvas Pada Jessen Cake Samarinda. eJournal Administrasi Bisnis, 7(2), 617-626. https://docplayer.info/183180326perancangan-business-model-canvaspada-jessen-cake-samarinda.html.

Mardiansa, F. (2017). Implementasi Business Model Canvas Sebagai Alternatif Strategi Bisnis Dalam Pengembangan Industri Kreatif (Studi Kasus Pada Usaha Papan Bunga Dian Florist Bandar Lampung). Jurnal Fakultas Ilmu Sosial dan Ilmu Politik. https://onesearch.id/Record/IOS4198.2 9937.

Meranga. (2019). Implementasi Business Model Canvas Pada Perusahaan Sosial. Jurakunman, 12(2), 43-55. http://jurakunman.stiesuryanusantara.ac .id/index.php/jur1/article/view/22.

Osterwalder, A. \& Pigneur, Y., (2010). Business model generation: a handbook for visionaries, game changers, and challengers (Vol. 1). John Wiley \& Sons.

Narto. (2017). Pengembangan Bisnis Model Untuk Meningkatkan Daya Saing Industri Batik Sumenep Madura. Prosiding SNST Fakultas Teknik, 1(1), 105-110. 
https://publikasiilmiah.unwahas.ac.id/in dex.php/Prosiding_SNST_FT/article/vi ew/1856/1911

Pasaribu, Munawir, \& Rizka Harfiani. (2019). Implementasi Business Model Canvas Pada CV. Media (Penerbit dan Distributor Buku Pelajaran PAUD). PUSKIBII (Pusat Kewirausahaan, Inovasi dan Inkubator Bisnis) Fakultas Ekonomi Dan Binis, 1(1), 201-208. https://doi.org/1030596/snk.v1i1.3607.

Ramadhani \& Putra. (2020). Strategi Pengembangan Model Bisnis Klaster Industri Tomat Krispi Daumato Berdasarkan Analisis SWOT dan BMC. Journal of Industrial View, 2(1), 33-42. http://jurnal.unmer.ac.id/index.php/jiv/a rticle/view/4211.

Rosello. (2019). Study of Strategic Drivers and Pattern that Change Planet's Business Model Canvas. UPCommons Global I access to UPC knowledge. https:/hdl.handle.net/2117/174627.

Rudy, T. K. (2016). Deskripsi Model Bisnis Pada PT Joyo Bekti Indah Menggunakan Business Model Canvas. AGORA 4(1), 591-600. http://publication.petra.ac.id/index.php/ manajemen-bisnis/article/view/6699

Sanim, B., Imam, T.S, \& Mawardi, B. (2016). Model Bisnis Ekowisata di Taman Nasional Laut Bunaken dengan Pendekatan Business Model Canvas. Manajemen IKM, 11 (1), 80-88. https://doi.org/1029.29244/mikm.11.1.8 $0-88$.

Sari, H. (2019). Strategi pengembangan Model Bisnis Dengan Menggunakan Pendekatan Triple Layer Business Model Canvas. Repository. http://repository.upi.edu/43533/.
Sultan, R., \& Imanuddin. H. (2018). Analisis Bisnis Model Kanvas pada Kadatuan Koffie Bandung. Jurnal Manajemen dan Bisnis, 2(2), http://journal.unla.ac.id/index.php/alma na/article/view/144.

Tantriana, D. (2018). Business Model Canvas Produk Simpanan Kencleng Koperasi Syariah Manfaat Surabaya. Manajemen, Akuntansi dan Perbankkan, 154-169. https://docplayer.info/115236524Business-model-canvas-produksimpanan-kencleng-koperasi-syariahmanfaat-surabaya-deasy-tantriana.html.

Vitayala, S., Hubeis, Agus, \& Eius, S. (2014). Analisis Model Bisnis Pada KNM Fish Farm Dengan Pendekatan Business Model Canvas (BMC). $J$. Sosek KP, 9(2), 195-210. http://ejournalbalitbang.kkp.go.id/index.php/sosek/art icle/view/1220.

Warnaningtyas, H. (2020). Desain Bisnis Model Canvas (BMC) Pada Usaha Batik Kota Madiun. Jurnal Managemen, Ekonomi Kreatif dan Bisnis, 9(2), 52-65. https://doi.org/10.33319/jeko.v9i2.6.

Widjaja, A. \& Aditya, D. S. (2019). Implementasi Sistem Penjualan Online berbasis E-Commerce Mengunakan Business Model Canvas Pada Cosy Distro. Jurnal Idealis, 2(5), 9-15. https://jom.fti.budiluhur.ac.id/index.php /IDEALIS/article/view/2490.

Winandi, R., Amzul, R., \& Muhamad, Z.L. (2019). Analisis Pengembangan Model Bisnis Kanvas perusahaan Hortikultura PT. XYZ. Forum Agribisnis, 9(2), 185199.

https://doi.org/10.29244/fagb.9.2.185199. 